\title{
Detection of Brucella spp. in milk from seronegative cows by real-time polymerase chain reaction in the region of Batna, Algeria
}

\author{
Rabehi Sabrina ${ }^{1}$, Hamdi Taha Mossadak², Mamache Bakir ${ }^{1}$, Meghezzi Asma ${ }^{3}$ and Boushaba Khaoula ${ }^{3}$
}

1. Department of Veterinary Science, Institute of Veterinary and Agronomic Sciences, University of Batna 1, Batna, Algeria; 2. Research Laboratory HASAQ, High National Veterinary School, Algiers, Algeria; 3. Laboratory of Molecular Biology and Microbiology of Constantine Biotechnology Research Center, Constantine, Algeria.

Corresponding author: Mamache Bakir, e-mail: mamachebakir@yahoo.fr

Co-authors: RS: sabrina.rabehi@yahoo.fr, HTM: moussahamdi@hotmail.com, MA: a.meghezzi@crbt.dz, BK: k. boushaba@crbt.dz.

Received: 03-12-2017, Accepted: 21-02-2018, Published online: 26-03-2018

doi: 10.14202/vetworld.2018.363-367 How to cite this article: Sabrina R, Taha Mossadak H, Bakir M, Asma M, Khaoula B (2018) Detection of Brucella spp. in milk from seronegative cows by real-time polymerase chain reaction in the region of Batna, Algeria, Veterinary World, 11(3): 363-367.

\begin{abstract}
Aim: The aim of this study was to detect Brucella spp. DNA in milk samples collected from seronegative cows using the real-time polymerase chain reaction (PCR) assay for diagnosis of brucellosis in seronegative dairy cows to prevent transmission of disease to humans and to reduce economic losses in animal production.
\end{abstract}

Materials and Methods: In this study, 65 milk samples were investigated for the detection of Brucella spp. The detection of the IS711 gene in all samples was done by real-time PCR assay by comparative cycle threshold method.

Results: The results show that of the 65 DNA samples tested, 2 (3.08\%) were positive for Brucella infection. The mean cyclic threshold values of IS711 real-time PCR test were 37.97 and 40.48, indicating a positive reaction.

Conclusion: The results of the present study indicated that the real-time PCR appears to offer several advantages over serological tests. For this reason, the real-time PCR should be validated on representative numbers of Brucella-infected and free samples before being implemented in routine diagnosis in human and animal brucellosis for controlling this disease.

Keywords: Brucella spp., milk, real-time polymerase chain reaction, seronegative cows.

\section{Introduction}

Brucellosis is one of the most common and economically important zoonoses globally [1]. Bacteria of the genus Brucella spp. are coccobacilli, Gramnegative, aerobic, non-spore forming, non-motile, and non-capsulated [2]. To date, twelve different Brucella species have been described $[3,4]$. Each one may infect different host species, but each Brucella species has a preference for its host species: Brucella melitensis (sheep and goats), Brucella abortus (cattle), Brucella suis (pigs), Brucella ovis (rams), Brucella canis (dogs), Brucella microti (rodents - Microtus arvalis), Brucella neotomae (rodents - Neotoma lepida), Brucella pinnipedialis (pinnipeds), Brucella ceti (cetacea), and Brucella inopinata (originally isolated from a human patient, but its preferential host is not known) [5-7]. The two most recently described species are $B$. papionis, which was isolated from two baboons with retained placenta [4], and Brucella vulpis which was isolated in Austria from the mandibular lymph nodes of two red foxes [3].

Copyright: Sabrina, et al. Open Access. This article is distributed under the terms of the Creative Commons Attribution 4.0 International License (http://creativecommons.org/licenses/ by/4.0/), which permits unrestricted use, distribution, and reproduction in any medium, provided you give appropriate credit to the original author(s) and the source, provide a link to the Creative Commons license, and indicate if changes were made. The Creative Commons Public Domain Dedication waiver (http:// creativecommons.org/publicdomain/zero/1.0/) applies to the data made available in this article, unless otherwise stated.
Zoonotic transmission occurs most frequently through unpasteurized milk products in urban settings, while occupational exposure of farmers, veterinarians, or laboratory workers can result from direct contact with infected animals or tissues or fluids associated with abortion [8].

Brucellosis in humans almost always originates from an animal reservoir [9]. To reduce the incidence of many zoonotic infections among humans, the pathogens must be controlled in the animal population [10].

Diagnosis is usually based on serological tests and/or cultivation. Serological assays are rapid, sensitive, and easy to perform but lack specificity due to cross-reactions with other bacteria, particularly with Yersinia enterocolitica O:9, that result from $\mathrm{O}$ chains antigenic similarity [11,12]. Conventional cultural isolation and identification of the agent is the gold standard test for Brucella abortus but time consuming, laborious and also need skills as well as biosafety level-3 laboratory and measures to prevent zoonosis [13].

Due to isolation problems, the significance of molecular-based detection techniques is increasing. Polymerase chain reaction (PCR) techniques for the diagnosis of Brucella spp. are used successfully both from different clinical samples and pure cultures [14].

There are also real-time or quantitative PCR (qPCR) assays that have been developed for rapid and safe detection of Brucella, including assays targeting the bcsp 31 gene or the $I S 711$ insertion sequence [15]. 
In this study, we discuss the extraction and purification of column DNA from raw milk using a specific kit, and we tried to use a reliable molecular procedure that could increase the sensitivity and specificity of the detection of Bruclla spp. DNA in bovine milk which detects insertion of the $I S 711$ sequence of B. melitensis, B. abortus, B. canis, B. ovis, and B. suis. IS711 is characteristic of Brucella spp. and appears in variable number (5-38 copies) [16].

\section{Materials and Methods \\ Ethical approval}

In this investigation, we did not use live animals. Milk samples were collected during routine milking by traditional hand-stripping. Therefore, no ethical approval was needed in the present study.

\section{Samples of milk}

A total of 65 milk samples were taken from seronegative cows (ages 3-8 years) belonging to 3 dairy farms in the Wilaya of Batna: 2 in the district of Djerma and 1 in the district of Ain Yagout. The first farm contains 21 cows, the second 25 cows, and the third 19 cows.

The milk samples were collected aseptically from teats of the udder which had previously been cleaned with water and soap, and then, the surface was sterilized with $70 \%$ ethanol. For each animal, the first jet of milk was removed, and then $15 \mathrm{~mL}$ of milk were collected from 4 quarters in sterile Falcon tubes previously identified. The samples were immediately transported to the laboratory at $+4^{\circ} \mathrm{C}$ for DNA extraction.

This study was conducted at the Laboratory of Microbiology and Molecular Biology of Constantine Biotechnology Research Center, Algeria, during July 2017.

\section{Pre-treatment of milk}

Initially, the milk undergone a pre-treatment as follows: A test sample of $800 \mu \mathrm{L}$ of the milk was centrifuged for $5 \mathrm{~min}$ at $10,000 \mathrm{~g}$, then the supernatant was removed, and the pellet was resuspended in 300 $\mu \mathrm{L}$ of phosphate-buffered saline.

\section{Extraction of DNA}

Genomic DNA was extracted from raw milk using a BioExtract ${ }^{\circledR}$ Column purification kit according to the manufacturer protocol (Cat $\left.\mathrm{N}^{\circ} \mathrm{BEC} 050\right)$.

The extracted DNA is then quantified using Nanodrop ${ }^{\circledR}$ ND 8000.

The DNA was then stored at $4{ }^{\circ} \mathrm{C}$ until use.

\section{Real-time PCR amplification}

Real-time PCR was used to detect the presence of Brucella spp. DNA in milk samples as described in the kit BactoReal ${ }^{\circledR}$ kit Brucella spp. (REF: DVEB02113). This test has been developed and validated for ABI PRISM $^{\circledR} 7500$ (Fast) instrument (Applied Biosystems). This test allows rapid and sensitive detection of DNA Brucella spp. from purified milk samples.

BactoReal ${ }^{\circledR}$ Kit Brucella spp. detects insertion of the IS711 sequence of B. melitensis, B. abortus, B. canis,
B. ovis, and B. suis. IS711 is characteristic of Brucella spp. and appears in variable number (5-38 copies).

A positive internal control of the system for the detection at Cy5 $(667 \mathrm{~nm})$ makes it possible to demonstrate the inhibitions of the PCR, resulting in false-negative results when interpreting the results due to the inhibition of PCR in real time.

\section{The reaction mixture}

The real-time PCR assay was performed by an ABI PRISM ${ }^{\circledR} 7500$ instrument thermal cycler (Applied Biosystems) using 96-well optical barcode plates (Ref: 4306737) and Adhesive Optical Films Starter Kit (Ref: 4311971) following the manufacturer's instructions (Ingenetix, Austria). The realtime PCR amplification was carried out in a reaction mixture of $20 \mu \mathrm{L}$ composed of $5 \mu \mathrm{L}$ of sample (or genomic DNA) containing matrix DNA and $15 \mu \mathrm{L}$ of Master Mix consisting of $3.0 \mu \mathrm{L}$ of water, $10 \mu \mathrm{L}$ of DNA mix reaction ( $1 \mu \mathrm{L}$ of Brucella Mix Assay) for the detection of Brucella spp., and $1 \mu \mathrm{L}$ of CR mix assay (Primers and Probes (Cy5) for IPC detection).

At least one negative control (water), one positive control (B. abortus), and one negative extraction included by PCR were ensured.

According to Ingenetix recommendations, all PCR analyzes are done in duplicate to optimize the probability of detecting pathogens and facilitates the interpretations of results.

\section{Programming of the temperature profile}

The reaction was carried out in a DNA thermocycler (Applied Biosystems) at a preliminary denaturing temperature of the DNA in dry at $95^{\circ} \mathrm{C}$, followed by 45 cycles consisting of $5 \mathrm{~s}$ at $95^{\circ} \mathrm{C}$ for denaturation of DNA, and $1 \mathrm{~min}$ at $60^{\circ} \mathrm{C}$ for polymerase-mediated primer extension.

\section{Results}

The results show that of the 65 DNA samples tested, $2(3.08 \%)$ were positive and 63 (96.92\%) were negative for brucellosis, based on real-time PCR testing used. The mean cyclic threshold $(\mathrm{Ct})$ values of IS711 real-time PCR test were 37.97 and 40.48, indicating a positive reaction.

The curve (Figure-1) shows a Target 1 (FAM Signal) multiplication which means that the Brucella spp. DNA was amplified and the sample interpreted as a positive. However, the $\mathrm{Ct}$ is 37.97 (low value) which means the presence of Brucella spp. in small quantities.

The curve (Figure-2) shows a Target 1 multiplication for positive controls (undiluted and diluted), as well as for 2 samples only. For the other samples, the Target 1 multiplication is not detectable (below the threshold value). The curves above the threshold value are Target 2 (Cy5) CPI multiplications.

\section{Discussion}

Brucellosis is an ancient and one of the world's most widespread zoonotic diseases affecting both public 


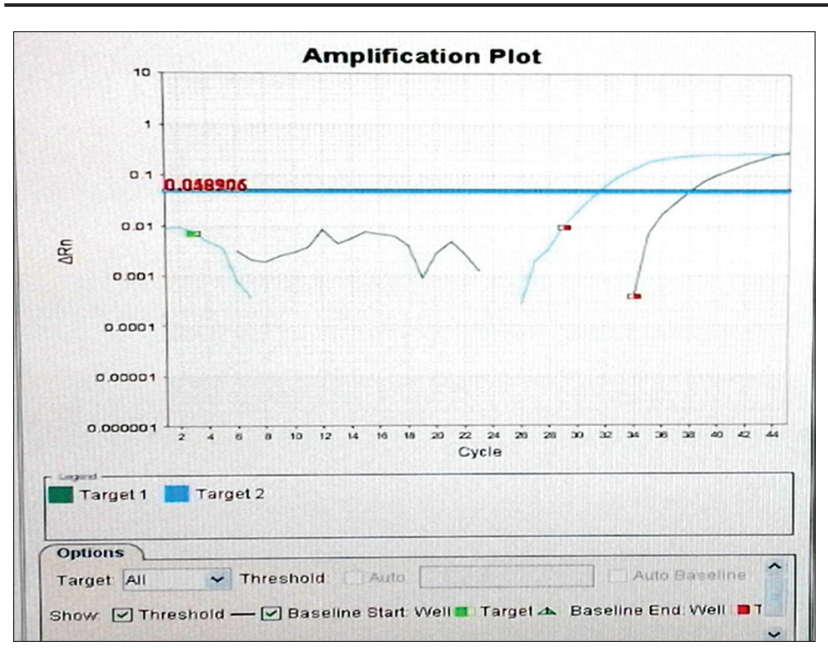

Figure-1: Logarithmic curve of amplification of one of the two positive samples. Target 1: FAM fluorescence signal of Brucella spp. DNA. Target 2: Fluorescence signal of the internal positive control (Cy5).

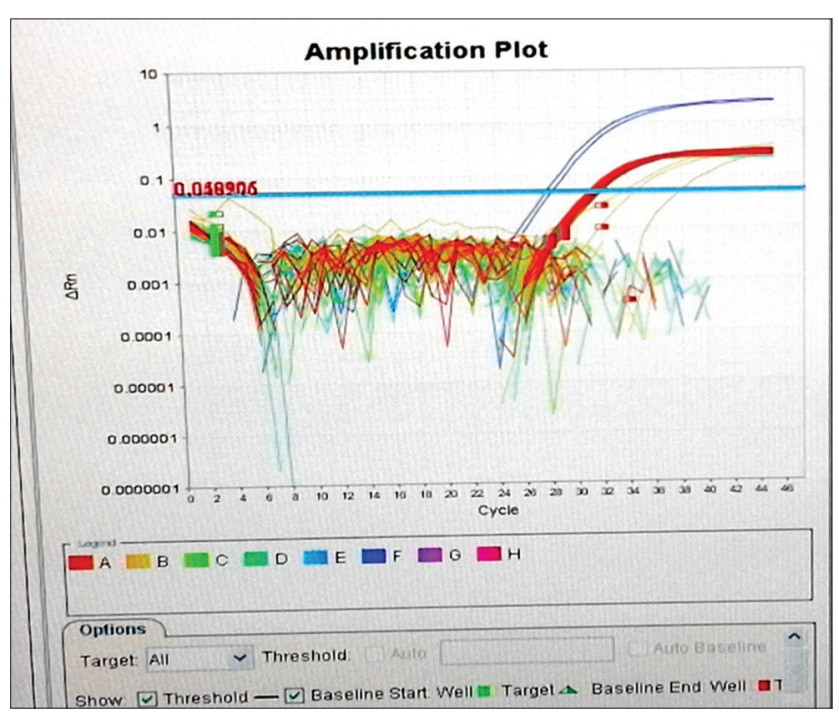

Figure-2: Logarithmic amplification curve of all samples (all plates even positive and negative controls).

health and animal production [17]. In livestock, the disease results in significant economic losses due to reproductive impairment caused by abortion, stillbirth or weak calves and neonatal mortality, and infertility [5]. In humans, Brucella spp. infection causes a febrile disease that may be associated with a broad spectrum of symptoms, and it may be fatal in some cases [18].

In the present study, we investigated the presence of Brucella DNA in the milk samples, and we chose to analyze all samples with primers targeting the IS711 insertion sequence because IS711 is a specific and highly sensitive method for the safe detection of the genus Brucella [15].

This study found that, of the 65 milk samples of seronegative cows, $3.08 \%(\mathrm{n}=2)$ were $\mathrm{qPCR}$ positive for Brucella DNA with Ct-values ranging between 37.97 and 40.48 . The results obtained in this study confirm that bacterial excretion of milk was low but sufficient to induce infection. The consumption of non-pasteurized dairy products from Brucella-infected animals is the most frequent route of human infection in general. Hence, pasteurization of milk will reduce Brucella transmission to humans [19].

The prevalence of brucellosis in Algeria in this study was lesser as compared to an earlier study obtained by Islam et al. [20], Rajala et al. [21], and Hinić et al. [22]. They found a similar level of positive cases among their examined herds with $11.23 \%$, $11.8 \%$, and $11.1 \%$, respectively. The discrepancy between the serology and PCR results observed in the current study might indicate that the true number of Brucella-infected cattle within the study area could be underestimated by serology screening. False serological negative results have been reported previously $[11,23,24]$ and one explanation could be that antibody titers reduce over time [25]. Hence, seronegative animals in the current study, which tested positive by qPCR, could have been exposed to Brucella and turned seronegative after a certain time period. Alternatively, if sampling at an early stage of the infection, i.e., within the first 14 days, the humoral immune response has not yet induced detectable levels of antibodies in the host [26]. Furthermore, individuals infected in utero or in the early post-natal period can become latently infected and hence never become seropositive [27]. Approximately $3.5 \%$ of infected cows are estimated to deliver latent-infected offspring [28]. In addition, MacMillan [29] reported that the Rose Bengal Test antigen could deteriorate when repeatedly cycled between refrigerator and room temperature during use. However, that serological testing has limits, especially after the disease has entered the chronic phase, when the organism is harbored intracellularly, often in the supramammary lymph nodes and the udder. Indeed, because the most important aspect of Brucella ecology is their ability to establish an intracellular replicative niche and remain protected from the host immune responses [2].

If this is the case, it might partially explain the discrepancy between the serology and qPCR results observed in the current study. Hypothetically, the discrepancy between the serology and qPCR results could be caused by previous vaccination against brucellosis as reported from a study in Egypt where cattle vaccinated with $R B 51$ tested negative by serology tests but positive by qPCR [30]. However, in the current study, the samples of milk were taken from dairy cows submitted a control program of 1995 that none of the cattle had been vaccinated against brucellosis in Algeria.

\section{Conclusion}

Real-time PCR appears to offer several advantages over serological test in detecting the presence of extensive infection in cow's milk samples. The detection was about $0.25 \mathrm{pg}$ DNA (equivalent to 25-50 cells). As amplicon production is monitored and measured in real-time, results are available within $30 \mathrm{~min}$ [24]. This insertion sequence IS711 appears in 
several copies (10-40) all over the genome, but distribution and number differ in Brucella species [31]. For this reason, it is highly recommended to use this real-time PCR procedure to identify Brucella in all types of milk samples. Furthermore, we advise to use this procedure as a regular screening test in farms animals.

\section{Authors' Contributions}

RS prepared the study design, carried out the research, and analyzed the data under the supervision of HTM and MB. RS and MA executed the extraction of DNA. RS and BK executed the real-time PCR. The manuscript was drafted and revised by RS under the guidance of HTM and MB. All authors read and approved the final manuscript.

\section{Acknowledgments}

The authors would like to thank the technical staff at the Laboratory of Microbiology and Molecular Biology of Constantine Biotechnology Research Center for their Collaboration, in particular, the Researcher Hamza Rahab, the Engineer Abderrahmane Selmania, and the responsible of Laboratory of Microbiology, Assia Ikhlef. The authors declare that they did not have any funding source or grant to support this research work.

\section{Competing Interests} interests.

The authors declare that they have no competing

\section{References}

1. McDermott, J., Grace, D. and Zinsstag, J. (2013) Economics of brucellosis impact and control in low-income countries. Rev. Sci. Tech. Int. Off. Epizoot., 32(1): 249-261.

2. Bargen, K., Gorvel, J.P. and Salcedo, S.P. (2012) Internal affairs: Investigating the Brucella intracellular lifestyle. FEMS Microbiol. Rev., 36: 533-562.

3. Scholz, H.C., Revilla-Fernández, S., Al Dahouk, S., Hammerl, J.A., Zygmunt, M.S., Cloeckaert, A., Koylass, M., Whatmore, A.M., Blom, J., Vergnaud, G., Witte, A., Aistleitner, K. and Hofer, E. (2016) Brucella vulpis sp. Nov., isolated from mandibular lymph nodes of red foxes (Vulpesvulpes). Int. J. Syst. Evol. Microbiol., 66: 2090-2098.

4. Whatmore, A.M., Davison, N., Cloeckaert, A., Al Dahouk, S., Zygmunt, M.S., Brew, S.D., Perrett, L.L., Koylass, M.S., Vergnaud, G., Quance, C., Scholz, H.C., Dick, E.J., Hubbard, G. and Schlabritz-Loutsevitch, N.E. (2014) Brucella papionis sp. Nov., isolated from baboons (Papio spp.) Int. J. Syst. Evol. Microbiol., 64: 4120-4128.

5. Xavier, M.N., Costa, E.A., Paixão, T.A. and Santos, R.L. (2009) Genus Brucella and clinical manifestation. Ciênc. Rural, 39(7): 2252-2260.

6. Scholz, H.C., Nöckler, K., Göllner, C., Bahn, P. Vergnaud, G., Tomaso, H., Al Dahouk, S., Huber, B., Busse, H.J. and De, B.K. (2010) Brucella inopinata sp. Nov., isolated from a breast implant infection. Int. J. Syst. Evol. Microbiol. 60(4): 801-808.

7. De Jong, M.F. and Tsolis, R.M. (2012) Brucellosis and Type IV secretion. Future Microbiol., 7: 47-58.

8. Olsen, S. and Palmer, M. (2014) Advancement of knowledge of Brucella over the past 50 years. Vet. Pathol., 51(6): 1076-1089.
9. Godfroid, J., Al Dahouk, S., Pappas, G., Roth, F., Matope, G., Muma J., Marcot-Ty, T., Pfeiffer, D. and Skjerve, E. (2013) A one health surveillance and control of brucellosis in developing countries: Moving away from improvisation. Comp. Immunol. Microbiol. Infect. Dis., 36: 241-248.

10. WHO. (2005) The Control of Neglected Zoonotic Diseases - A Route to Poverty Alleviation. Report of a Joint WHO/DFID-AHP Meeting with the Participation of FAO and OIE. WHO, Geneva. Available from: http://www.who. int/zoonoses/Report_Sept06.pdf. Accessed on 11-02-2018.

11. Godfroid, J., Saegerman, C., Wellemans, V., Walravens, K., Letesson, J.J., Tibor, A., McMillan, A., Spencer, S., Sanna, M. and Bakker, D. (2002) How to substantiate eradication of bovine brucellosis when aspecific serological reactions occur in the course of brucellosis testing. Vet. Microbiol., 90: 461-477.

12. Nilsen, K., Smith, P., Widdison, J., Gall, D., Kelly, L., Kelly, W. and Nicoletti, P. (2004) Serological relationship between cattle exposed to Brucella abortus, Yersinia enterocolitica: 9 and Escherichia coli O157: H7. Vet. Microbiol., 100: 25-30.

13. Taleski, V. (2010) An overview of introducing various laboratory tests for diagnostic of human brucellosis in the Republic of Macedonia. Macedonian J. Med. Sci., 3: $239-245$.

14. Kumar, S., Tuteja, U., Sarika, K., Singh, D.K., Kumar, A. and Kumar, O. (2011) Rapid multiplex PCR assay for the simultaneous detection of the Brucella genus, B. abortus, B. melitensis, and B. suis. J. Microbiol. Biotechnol., 21: 89-92.

15. Bounaadja, L., Albert, D., Chénais, B., Hénault, S., Zygmunt, M.S., Poliak, S. and Garin-Bastuji, B. (2009) Real-time PCR for identification of Brucella spp.: A comparative study of IS711, bcsp31 and per target genes. Vet. Microbiol., 137: 156-164.

16. Kit manufactures BactoReal ${ }^{\mathbb{R}}$ KitBrucella spp. (2014). Ingenetix $\mathrm{GmbH}$ Austria.

17. Ariza, J., Bosilkovski, M., Cascio, A., Colmenero, J.D., Corbel, M.J., Falagas, M.E., Memish, Z.A., Roushan, M.R.H., Rubinstein, E., Sipsas, N.V., Sipsas, N.V., Solera, J., Young, E.J. and Pappas, G. (2007) Perspectives for the treatment of brucellosis in the $21^{\text {st }}$ century: The ioannina recommendations. PLoS Med., 4(12): e317.

18. Cutler, S.J., Whatmore, A.M. and Commander, N.J. (2005) Brucellosis-new aspects of an old disease. J. Appl. Microbiol., 98(6): 1270-1281.

19. Rubach, M.P., Halliday, J.E., Cleaveland, S. and Crump, J.A. (2013) Brucellosis in low-income and middle-income countries. Curr. Opin. Infect. Dis., 26: 404-412.

20. Islam, M.R.U., Pratap, G.M., Kaur, S.P., Filia, G., Mohan, S.H. and Ahmed, S.T. (2013) Comparative evaluation of indirect enzyme linked immunosorbent assay, rose bengal plate test, microagglutination test, and polymerase chain reaction for diagnosis of brucellosis in buffaloes. Turk. J. Vet. Anim. Sci., 37: 306-310.

21. Rajala, E.L., Hoffman, T., Fretin, D., Godfroid, J., Sattorov, N., Boqvist, S., Lundkvist, A. and Magnusson, U. (2017) Detection and characterization of Brucella spp. PLoS Negl. Trop. Dis., 11(3): e0005367.

22. Hinić, V., Brodard, I., Thomann, A., Holub, M., Miserez, R. and Abril, C. (2009) IS711-based real-time PCR assays as a tool for detection of Brucella spp. in wild boars and comparison with bacterial isolation and serology. BMC Vet. Res., 5: 22.

23. Maills, A., Rautureau, S., Le Horgne, J., Poignet-Leroux, B., d'Amoux, C., Dennetière, G., Faure, M., Lavigne, J.P., Bru, J.P. and Garin-Bastuji, B. (2012) Re-emergence of brucellosis in cattle in France and risk for Human health. Euro Surveill, 17(30): 20227. Available from: http://www. eurosurveillance.org/ViewArticle. aspx?ArticleId=20227. Accessed on 13-07-2017.

24. Al Dahouk, S., Tomaso, H., Nöckler, K., Neubauer, H. and Frangoulidis, D. (2003) Laboratory based diagnosis of 
brucellosis - a review of the literature. Part II: Serological tests for brucellosis. Clin. Lab., 49(11-12): 577-589.

25. Godfroid, J., Nielsen, K. and Saegerman, C. (2010) Diagnosis of brucellosis in livestock and wildlife. Croat. Med. J., 51: 296-305.

26. Gardner, I.A., Stryhn, H., Lind, P. and Collins, M.T. (2000) Conditional dependence between tests affects the diagnosis and surveilance of animal diseases. Prev. Vet. Med., 45: 107-122.

27. Corbel, M.J. (2006) Brucellosis in humans and animals, World Health Organization in collaboration with the Food and Agriculture Organization of the United Nations and World Organization for Animal Health. Available from: http://www.who.int/csr/resources/publications/Brucellosis. pdf. Accessed on 12-10-2016.

28. Saegerman, C., Berkvens, D., Godfroid, J. and
Walravens, K. (2010) Bovine brucellosis. In: Lefévre, P.C., Blancou, J., Chermette, R. and Uilenberg, G., editors. Infectious and Parasitic Disease of Livestock. Lavoisier and Commonwealth Agricultural Bureau - International, Paris, France. p. 971-1001.

29. MacMillan, A. (1990) Conventional serological test. In: Nielsen, K. and Duncan, J.R., editors. Animal Brucellosis. CRC Press, Boca Raton. p. 153-197.

30. Gwida, M., El-Ashker, M., Melzer, F., El-Diasty, M., El-Beskawy, M. and Neubauer, H. (2016) Use of serology and real time PCR to control an outbreak of bovine brucellosis at a dairy cattle farm in the Nile Delta region, Egypt. Ir. Vet. J., 69: 3.

31. Halling, S.M., Tatum, F.M. and Bricker, B.J. (1993) Sequence and characterization of an insertion sequence, IS711, from Brucella ovis. Gene, 133: 123-127.

$* * * * * * * *$ 